Herz 2020 · 45:316-318

https://doi.org/10.1007/s00059-020-04928-w

Published online: 24 April 2020

(c) Springer Medizin Verlag $\mathrm{GmbH}$, ein Teil von Springer Nature 2020

Anselm K. Gitt ${ }^{1,2} \cdot$ Alexandra Bernhardt $^{3} \cdot$ Ralf Zahn $^{1} \cdot$ Uwe Zeymer $^{1,2} \cdot$ Armin Grau $^{4}$ • Manfred E. Beutel ${ }^{5} \cdot$ Karl Werdan $^{6}$

${ }^{1}$ Medizinische Klinik B, Klinikum der Stadt Ludwigshafen/Rhein, Ludwigshafen, Germany

${ }^{2}$ Stiftung Institut für Herzinfarktforschung, Klinikum der Stadt Ludwigshafen/Rhein, Ludwigshafen, Germany

${ }^{3}$ Institut für Herzinfarktforschung GmbH, Ludwigshafen, Germany

${ }^{4}$ Neurologische Klinik, Klinikum der Stadt Ludwigshafen/Rhein, Ludwigshafen, Germany

${ }^{5}$ Klinik und Poliklinik für Psychosomatische Medizin und Psychotherapie, Universitätsklinik Main, Mainz, Germany

${ }^{6}$ Universitätsklinik und Poliklinik für Innere Medizin III, Universitätsklinikum Halle (Saale) der MartinLuther-Universität Halle-Wittenberg, Halle (Saale), Germany

\title{
The COVID-19 Registry in Rhineland-Palatinate in the context of international registry activities documenting COVID-19 outcomes
}

\section{Rationale of COVID-19 registries}

The global spread of Coronavirus SARSCoV-2 (SARS-CoV-2) was declared a pandemic by the World Health Organization (WHO) on March 11, 2020 and is currently posing major challenges for health care systems around the world . Besides the planning of intensive care resources, the lack of evidence-based therapy options is a particular problem for the treating physicians. General statements on the typical course of SARSCoV-2 infection cannot be made reliably at present. Disease patterns are unspecific, diverse, and vary widely, from asymptomatic courses to severe complications, such as pneumonia with lung failure, cardiovascular and cerebral manifestations, and ultimately death. Symptoms include fever, cough, and shortness of breath as well as neurological and cardiac manifestations [1]. Risk groups are mainly older people (with a steadily increasing risk of severe courses from above 50-60 years of age), smokers, and patients with certain preexisting conditions (e.g., cardiovascular diseases, lung diseases, diabetes mellitus, cancer, and weakened immune system $[2,3])$. Therefore, standardized and coordinated data collection on a large scale is of pivotal importance to learn about the natural course of the disease, to accelerate knowledge on the role of preexisting comorbidities in the COVID19 pandemic, and to identify factors associated with outcomes.

\section{Planned and already enrolling COVID-19 registry activities in Germany and Europe}

There are a plethora of planned and ongoing activities documenting the COVID19 disease patterns using chart reviews or collecting prospective data. In Germany, many professional medical societies are currently planning or setting up registries for COVID-19 patients with different focuses on disease patterns and specific pre-existing conditions in their scientific fields, e.g., in patients with rheumatic diseases (DGRh-Deutsche Gesellschaft für Rheumatologie e. V.) or in patients with renal diseases (DGfN-Deutsche Gesellschaft für Nephrologie). In addition, large private hospital groups such as
HELIOS announced data collection and analysis of COVID-19 patients in their hospitals. Most of these activities are in a planning stage and little information is available in the public domain to date.

Currently, three large-scale prospective data collections are already ongoing: the international LEOSS registry (Lean European Open Survey on SARS-CoV-2 Infected Patients), the CAPACITYCOVID registry (registry of patients with COVID-19 including cardiovascular risk and complications), and the German COVID-19-RLP-Registry. Both LEOSS and CAPACITY-COVID have received support by national and international professional organizations; the CAPACITY-COVID registry was started in The Netherlands and recently endorsed by the European Society of Cardiology (ESC) for international enrolment. Study designs, objectives, and planned outcome analyses are summarized in $\bullet$ Table 1. The expert committees of COVID-19RLP, LEOSS, and CAPACITY-COVID have exchanged their codebooks to ensure consistency and comparability of data collection. Data collection of the ongoing activities is an extension of 


\begin{tabular}{|c|c|c|c|}
\hline Registry & COVID-19-RLP & LEOSS & CAPACITY-COVID [4] \\
\hline $\begin{array}{l}\text { Initiated/Run } \\
\text { by }\end{array}$ & IHF, Germany & DZIF, Germany & UMC Utrecht, Netherlands \\
\hline $\begin{array}{l}\text { Involved } \\
\text { specialties }\end{array}$ & $\begin{array}{l}\text { Cardiology/Internal Medicine Neurology/ } \\
\text { Psychosomatic Medicine }\end{array}$ & $\begin{array}{l}\text { Infectious Diseases (inviting all } \\
\text { other specialties for participation } \\
\text { in LEOSS.deep) }\end{array}$ & Cardiology \\
\hline $\begin{array}{l}\text { Participating } \\
\text { countries }\end{array}$ & Germany & EU countries & EU countries \\
\hline Study type & $\begin{array}{l}\text { Observational disease registry } \\
\text { (cross-sectional/longitudinal) }\end{array}$ & $\begin{array}{l}\text { Observational disease registry/survey } \\
\text { (cross-sectional) }\end{array}$ & $\begin{array}{l}\text { Observational disease registry } \\
\text { (cross-sectional/longitudinal) }\end{array}$ \\
\hline $\begin{array}{l}\text { Inclusion } \\
\text { criteria }\end{array}$ & $\begin{array}{l}\text { Inpatients with confirmed } \\
\text { SARS-CoV-2 infection }\end{array}$ & $\begin{array}{l}\text { Inpatients with confirmed } \\
\text { SARS-CoV-2 infection }\end{array}$ & $\begin{array}{l}\text { Inpatients with highly sus- } \\
\text { pected/confirmed with SARS- } \\
\text { CoV-2-infection; } \geq 18 \text { years }\end{array}$ \\
\hline Status & Recruiting & Recruiting & Recruiting \\
\hline $\begin{array}{l}\text { Outcome } \\
\text { measures }\end{array}$ & $\begin{array}{l}\text { In-hospital outcome with specific focus on cardiovas- } \\
\text { cular, neurological complications }\end{array}$ & In-hospital outcome & $\begin{array}{l}\text { In-hospital outcome with specific } \\
\text { focus on cardiovascular complica- } \\
\text { tions }\end{array}$ \\
\hline Follow-up & $\begin{array}{l}\text { Planned at } 30 \text { days and } 3 \text { months } \\
\text { with specific focus on cardiovascular, neurological, } \\
\text { mental health, and psychosocial complications }\end{array}$ & None & $\begin{array}{l}\text { Planned at } 7 \text { and } 30 \text { days } \\
\text { with specific focus on cardiovascu- } \\
\text { lar complications }\end{array}$ \\
\hline
\end{tabular}

the Case Record Form (CRF) that was released by the ISARIC (International Severe Acute Respiratory and Emerging Infection Consortium) and the WHO for data collection in the COVID-19 pandemic, ensuring comparability of data but focusing on specific aspects of the disease. Due to the prospective design of COVID-19-RLP and CAPACITYCOVID with patients' informed consent both registries have planned short- and mid-term follow-ups of the enrolled patients (•Table 1).

\section{COVID-19-RLP}

The aim of COVID-19-RLP is to document all consecutive patients undergoing in-hospital treatment in RhinelandPalatinate hospitals for a SARS-CoV-2 infection. Target variables are the clinical status at admission, pre-existing conditions, laboratory parameters, therapeutic strategies, and the course of the disease. The primary objectives are (a) to characterize patients with SARSCoV-2 infection requiring in-hospital treatment in Rhineland-Palatinate, (b) to describe the current therapeutic strategies, (c) to document the complications (with a special focus on cardiovascular and cerebrovascular events) and mortality of SARS-CoV-2 infection, and (d) to develop a risk stratification for severe disease progression, which could potentially contribute to a prediction of the need for ventilation and thus to better planning of resources. The study is supported by the Ministry of Social Affairs, Labor, Health, and Demography of Rhineland-Palatinate and conducted in accordance with the World Medical Association-Declaration of Helsinki-Ethical Principles for Medical Research Involving Human Subjects and approved by the ethics committee of the Landesärztekammer RheinlandPfalz. The study is registered at ClincialTrials.gov (NCT04335188). Eligible for enrolment are all patients with confirmed SARS-CoV-2 infection undergoing in-hospital treatment. A total of 84 hospitals in Rhineland-Palatinate in Germany treating patients with SARSCoV-2 infection are eligible for participation and have started enrolment on April 6, 2020. All data collected are web-based using the software solution EBogen $\subsetneq$. During documentation, plausibility and completeness checks are generated immediately. All data are transferred with SSL encryption standard and stored on a server of the Institut für Herzinfarktforschung Ludwigshafen (IHF). Descriptive statistics on the registry population, the applied therapeutic measures, and the clinical course will be generated. Subgroup analyses for risk stratification are planned and defined in a detailed statistical analysis plan.

\section{Perspective}

Despite the current additional significant workload of clinically active physicians involved in the care of patients of the COVID-19 pandemic, different groups have put a lot of effort into the initiation of a number of prospective planned registry studies to better understand the natural course of this new infectious disease. Scientific collaborations are already planned and should be continued to ensure data consistency and comparability. We look forward to obtaining additional data on the short- and mid-term course of the disease with prospective follow-ups of hospital survivors in the COVID-19-RLP as well as in the CAPACITY-COVID registries with specific focus on cardiovascular and neurological outcomes. COVID-19-RLP in addition will also collect data on the yet-unknown consequences for mental health and the psychosocial outcomes of survivors of COVID-19. 


\section{Corresponding address}

\section{Anselm K. Gitt, MD}

Stiftung Institut für Herzinfarktforschung, Klinikum der Stadt Ludwigshafen/Rhein Bremser Str. 79, 67063 Ludwigshafen, Germany gitta@klilu.de gitt@stiftung-ihf.de

Conflict of interest. A.K. Gitt, A. Bernhardt, R. Zahn, U. Zeymer, A. Grau, M.E. Beutel, and K. Werdan declare that they have no competing interests.

\section{References}

1. Mao $L$, Jin $H$, Wang $M$ et al (2020) Neurologic manifestations of hospitalized patients with coronavirus disease 2019 in Wuhan, China. JAMA Neurology. https://doi.org/10.1001/jamaneurol. 2020.1127

2. Xiong TY, Redwood S, Prendergast B et al (2020) Coronaviruses and the cardiovascular system: acute and long-term implications. Eur Heart J 0:1-3. https://doi.org/10.1093/eurheartj/ ehaa231

3. Grasselli G, Zangrillo A, Zanella A (2020) Baseline characteristics and outcomes of 1591 patients infected with SARS-CoV-2 admitted to ICUs of the Lombardy region, Italy. JAMA. https://doi.org/10. 1001/jama.2020.5394

4. Linschoten M, Asselbergs FW (2020) CAPACITYCOVID: a European registry to determine the role of cardiovascular disease in the COVID-19 pandemic. Eur Heart J. https://doi.org/10.1093/eurheartj/ ehaa280

Vorhofflimmern: Sport und Ausdauertraining schützen vor lästigen Anfällen

Menschen mit Vorhofflimmern leiden oftmals sehr an den Anfällen aus dem linken Vorhof ihres Herzens. Das Herz rast dann bis zu einem Puls von bis zu 160 Schlägen pro Minute. „Wie aus dem Nichts kann das Herz bei solchen Flimmeranfällen bis zum Hals schlagen und beginnen zu rasen. Oftmals kommen Druckgefühl im Brustkorb, Luftnot Schwindel und ein Angstgefühl hinzu", beschreibt Herzspezialist Prof. Dr. med. Bernd Nowak vom Wissenschaftlichen Beirat der Deutschen Herzstiftung die Attacken dieser häufigsten Herzrhythmusstörung - fast 2 Millionen Menschen sind in Deutschland betroffen. Umso mehr Erleichterung bei Vorhofflimmerpatienten, wenn die lästigen Anfälle seltener werden oder gar nicht mehr auftreten. Was viele Betroffene nicht wissen: Sie können selbst viel gegen die unangenehmen Episoden tun. „Für Patienten mit Vorhofflimmern sind Sport und Gewichtsabnahme ganz entscheidend, um ihr Risiko für erneute Vorhofflimmeranfälle dramatisch zu senken", bestätigt Nowak in dem Herzstiftungs-Ratgeber "Herz außer Takt: Vorhofflimmern". Der Experten-Band kann kostenfrei unter www.herzstiftung.de/vorhofflimmernratgeber.html oder per Tel. unter 069 955128400 angefordert werden. Patienten mit Vorhofflimmern wird ein niedrig bis mäßig dosiertes Ausdauertraining empfohlen, möglichst 20-30 Minuten drei- bis fünfmal pro Woche: beispielsweise flottes Gehen, Joggen, Rudern, Walken, Radfahren, Ergometertraining oder Tanzen. Oder anders formuliert: $60-120$ Minuten Ausdauertraining die Woche an 3 bis 5 Tagen. Niedrig dosiertes Krafttraining sollte auch Trainingsbestandteil für Patienten mit Vorhofflimmern sein: „Ältere Menschen, die besonders häufig von dieser Rhythmusstörung betroffen sind, riskieren mit Krafttraining weniger Stürze und kommen im Alltag besser zurecht", berichtet Nowak. Und überhaupt: Sport und Ausdauerbewegung sind für Patienten mit Vorhofflimmern für eine Verbesserung ihres Herzleidens ebenso entscheidend wie für Patienten mit anderen Herz-Kreislauf-Erkrankungen wie Herzschwäche, koronare Herzkrankheit und Bluthochdruck. „Allerdings sollte man die Trainingsdosis immer mit dem Arzt ermitteln", betont der Kardiologe am Cardioan- giologischen Centrum Bethanien - CCB in Frankfurt am Main. Vorhofflimmerpatienten, die zum Beispiel Betablocker oder Rhythmusmedikamente einnehmen, müssen mit Einbußen ihrer körperlichen Leistungsfähigkeit aufgrund dieser Herzmedikamente rechnen. Also ist zuerst in einem Belastungstest beim Kardiologen oder Sportmediziner der optimale Trainingspuls zu bestimmen. Kann ein Vorhofflimmerpatient seine Belastbarkeit um mehr als 50 Watt steigern, was einem schnelleren Gehen entspricht, wird das Risiko für erneutes Vorhofflimmern über eine FünfJahres-Periode um 37 Prozent verringert. "Also ein Rückgang um mehr als ein Drittel", so Nowak. Nehme man zusätzlich 10 Prozent an Körpergewicht ab und steigere seine Belastbarkeit um mehr als 50 Prozent, lasse sich das Risiko erneuter Vorhofflimmeranfälle sogar um drei Viertel senken. „Der Effekt ist so groß, wie man ihn mit Medikamenten kaum erreichen kann." Die positiven Effekte von Ausdauerbewegung zeigen sich auch bei Patienten nach einer Katheterablation: „Wenn man die Risiken aggressiv behandelt und die Patienten vermehrt trainieren, werden die Langzeitergebnisse der Ablation weiter verbessert", sagt der Arzt. Wer noch kein Vorhofflimmern hat, kann durch stärkeres regelmäßiges Training der Herzrhythmusstörung vorbeugen und so sein Schlaganfallund Sterblichkeitsrisiko senken. Da Vorhofflimmeranfälle ganz plötzlich auftreten und mit Atemnot und Schwächeanfällen einhergehen können, kann etwa Schwimmen im Meer oder in anderen Gewässern gefährlich sein. Auch Klettern oder exponiertes Bergwandern, zum Beispiel über einen Grat, sollte man vermeiden. Patienten, die für die Schlaganfallprophylaxe Gerinnungshemmer einnehmen sollten ein Auge darauf haben, ob ihr Sport verletzungsträchtig ist. Das ist bei Mountainbiking, Snowboarding, bei Ski alpin auf schnellen sehr vollen Pisten oder bei Kampfsportarten wie Boxen, Karate, JiuJitsu usw. der Fall. „Da ist die Gefahr von folgenreichen Blutungen in die Muskeln, in die Gelenke und in die inneren Organe erhöht. Dieses Risiko sollte man nicht eingehen", so Prof. Nowak. 